\title{
Effects of DMI and strobilurin fungicide combinations on scab and powdery mildew incidence in apple production: a preliminary study
}

\author{
Holb, I.J., Kocsis, M., Kruppa, J. \& Abonyi, F. \\ Centre of Agricultural Sciences, University of Debrecen 138 Böszörményi St., 4032 Debrecen, Hungary
}

\begin{abstract}
Summary: The aim of our study was to evaulate the effectiveness of four DMI and strobilurion fungicide combinations in a season-long disease management programme against apple scab and powdery mildew in two integrated apple orchards on cultivar Jonagold. The four spray programmes were: i) standard, ii) DMI dominant iii) strobilurin dominant, and iv) DMI and strobilurin dominant. Apple scab incidence was generally high in both orchards in the standard fungicide treatment plots ranged between 21.8 and $26.4 \%$. Leaf scab incidence was higher in all treatments compared to fruit incidence. Scab incidence was generally higher at Mándok compared to Ófehértó. In both locations the lowest scab incidence was assessed in DMI dominant treatment ranged between 5 to $10.7 \%$, which was not significantly different from the DMI and strobilurin dominant treatment. Powdery mildew incidence was generally low in both orchards in all fungicide treatments ranged between 0.002 and $0.5 \%$. Although there were no significant differences among treatments, the lowest powdery mildew incidence was assessed in the DMI and strobilurin dominant treatment in Mándok and in the strobilurin dominant treatment in Ófehértó..
\end{abstract}

Key words: apple, DMI, scab, strobilurin, powdery mildew, integrated

\section{Introduction}

Rules and several tools for fungal disease management are well-defined and most of them are successfully implemented for environmentally friendly productions systems in apple (e.g. Zalom, 1993). Disease management practices in integrated apple production differ markedly from those in conventional production. Synthetic products are restricted in integrated apple production. Growers can use only those fungicides which are sorted into 'green' and 'yellow' list of active ingredients by the international integrated fruit production guidelines, while many synthetic pesticides can be used in conventional apple production.

In integrated apple orchards the most often used systemic fungicides are DMIs and strobilurins against the key diseases such as apple scab and powdery mildew (e.g. Koller et al., 1997; Holb et al., 2005, 2009). The extensive use of DMI and strobilurin fungicides resulted in fungicide sensitivity reduction or fungicide resistance in apple scab and powdery mildew (e.g., Délye et al., 1997; Koller et al., 1997; Hollomon \& Wheeler, 2002; Jobin \& Carisse, 2007). Several resistance management strategies were developed to avoid apple scab resistance to DMI fungicides but an overall solution is still under development. One of the most essential difficulties is cross-resistance occurring among DMI fungicides, which makes more difficult to plan an effective disease management strategy (e.g. Koller et al., 1997). Various combinations of DMI and stobilurin fungicides in a season-long disease management programme may contribute to a successful fungicide resistance strategy for both fungicide groups in the control of apple scab and apple powdery mildew.

The aim of our study was to evaluate the effectiveness of three DMI and strobilurion fungicide combinations in a season-long disease management programme against apple scab and powdery mildew. The study was performed in two integrated apple orchards on a scab susceptible apple cultivar Jonagold.

\section{Materials and Methods}

Four fungicide spray programmes were performed in two integrated apple orchards at Ófehértó and Mándok, respectively, in Eastern Hungary. The orchards were established in 2003 and 1997, respectively, and grafted on M26 rootstock. Both orchards followed the Hungarian integrated fruit production guidelines from the establishment of the plantations. The main cultivars of the orchards were 'Jonagold' and 'Idared'. The experiment was done on cultivar 'Jonagold'. The applied fungicides in the spray programmes were: Delan 700WG (dithianon), Chorus 50WG (cypronidil), Merpan 80WDG (captan), Kumulus S (elementary sulphur), Score 250EC (difenoconazole) Clarinet (pyrimethanil+fluquinconazole), Rézoxiklorid 50WP (copper oxyclhoride), Dithane M-45 (mancozeb), Folicur Solo (tebuconazole), Tercel (dithianon+pyraclostrobin), and Sillit 400SC (dodine).

In our preliminary study, altogether four spray programmes of DMI and stobilurion fungicide combinations were 
performed in 2010. The four spray programmes were: i) standard (STD): sprays followed by general orchard practices followed by the IFP guidelines, ii) DMI dominant (DMI 30): proportion of DMI fungicides above $30 \%$ while the proportion of strobilurin fungicides under $10 \%$ in the season-long spray programme, iii) strobilurin dominant (STR 30): proportion of strobilurin fungicides above $30 \%$ while the proportion of DMI fungicides under $10 \%$ in the season-long spray programme and iv) DMI and strobilurin dominant (DMI 30 + STR 30): proportion of both DMI and strobilurin fungicides above $30 \%$ in the season-long spray programme.

At the second half of August, incidence of apple scab on fruits and leaves and incidence of powdery mildew on shoots were assessed in each treatment. Five trees, replicated four times, were assessed for each treatment. 100 leaves/fruits/ shoots per tree were selected randomly and counted for disease symptoms. Differences among spray programmes were tested separately for the two locations and for the two diseases. Statistaics were performed by ANOVA at $\mathrm{P}=0.05$ level using LSD test.

\section{Results and Discussion}

Apple scab incidence was generally high in both orchards in the standard fungicide treatment plots ranged between 21.8 and $26.4 \%$ (Figures 1 and 2). Leaf scab incidence was higher in all treatments compared to fruit incidence. Scab incidence was generally higher at Mándok compared to Ófehértó. In both locations the lowest scab incidence was assessed in DMI dominant treatment ranged between 5 to $10.7 \%$, which was not significantly different from the DMI and strobilurin dominant treatment. The incidences of leaf and fruit scab were generally higher than those reported in previous studies in integrated apple orchards (e. g. Holb at al., 2005, 2006, Holb, 2006) The high incidence of leaf and fruit scab in this study was due to favorable weather conditions to scab infection, large inoculum sources presented in the orchards and poor management options during primary infection periods.

Powdery mildew incidence was generally low in both orchards in all fungicide treatments ranged between 0.002 and

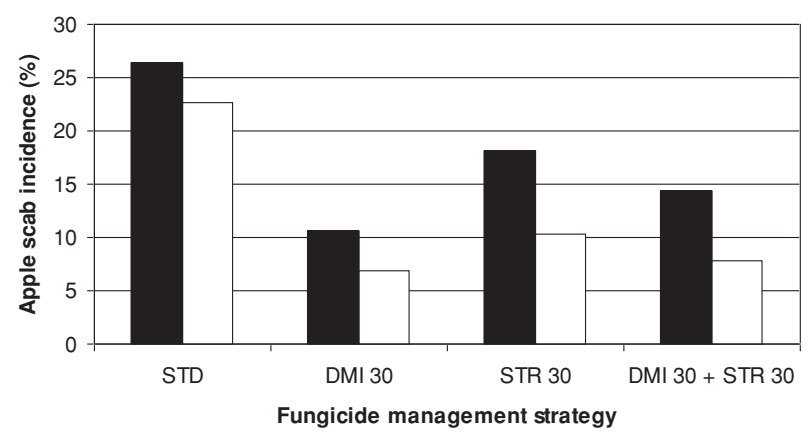

Figure 1. Efficacy of DMI and strobilurin spray programmes $(\mathrm{STD}=$ Standard, DMI 30 = DMI dominant, STR 30 = strobilurin dominant, DMI $30+$ STR $30=$ DMI and strobilurin dominant) on apple scab incidence on leaves (black coloumn) and fruits (white coloumn) of cultivar Jonagold in 2010 at Mándok $\left(\operatorname{LSD}_{0.05}=6.2-\right.$ leaf; $\operatorname{LSD}_{0.05}=4.4-$ fruit $)$.

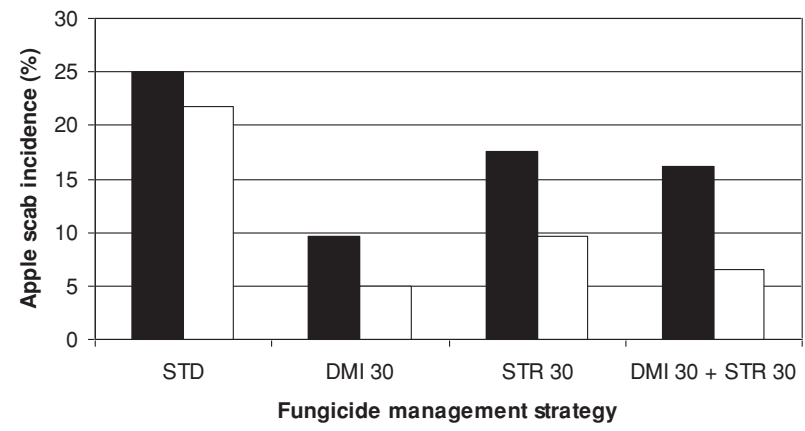

Figure 2. Efficacy of DMI and strobilurin spray programmes $(\mathrm{STD}=$ Standard, DMI 30 = DMI dominant, STR 30 = strobilurin dominant, DMI $30+$ STR $30=$ DMI and strobilurin dominant) on apple scab incidence on leaves (black coloumn) and fruits (white coloumn) of cultivar Jonagold in 2010 at Ófehértó $\left(\operatorname{LSD}_{0.05}=5.1-\right.$ leaf; $\operatorname{LSD}_{0.05}=4.2-$ fruit $)$.

$0.5 \%$ (Figures 3 and 4 ). Although there were no significant differences among treatments, the lowest powdery mildew incidence was assessed in the DMI and strobilurin dominant treatment in Mándok and in the strobilurin dominant treatment in Ófehértó. Low powdery mildew incidence was reported also in previous apple studies in integrated orchards (Holb, 2005; Holb et al., 2009). The low incidence of powdery mildew in this study was due to good efficacy of scab fungicides against powdery mildew, small amount of inoculum sources in the orchards and moderate susceptibility of cultivar 'Jonagold' to powdery mildew.

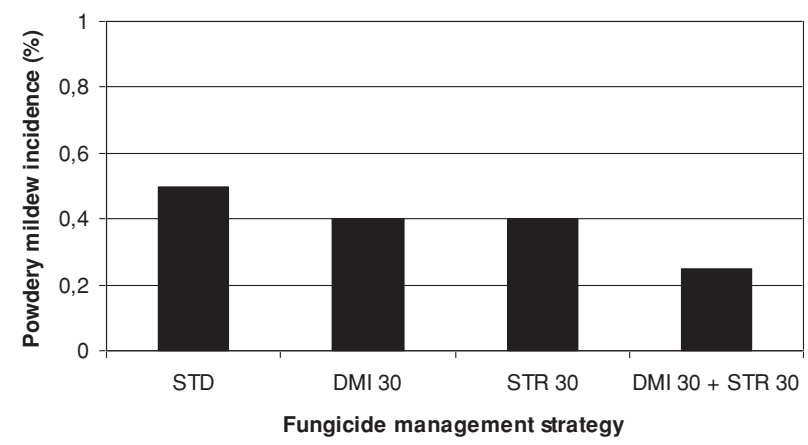

Figure 3. Efficacy of DMI and strobilurin spray programmes $(\mathrm{STD}=$ Standard, DMI 30 = DMI dominant, STR 30 = strobilurin dominant, DMI 30 + STR $30=$ DMI and strobilurin dominant) on powdery mildew incidence on shoot of cultivar Jonagold in 2010 at Mándok $\left(\operatorname{LSD}_{0.05}=0.7\right)$.

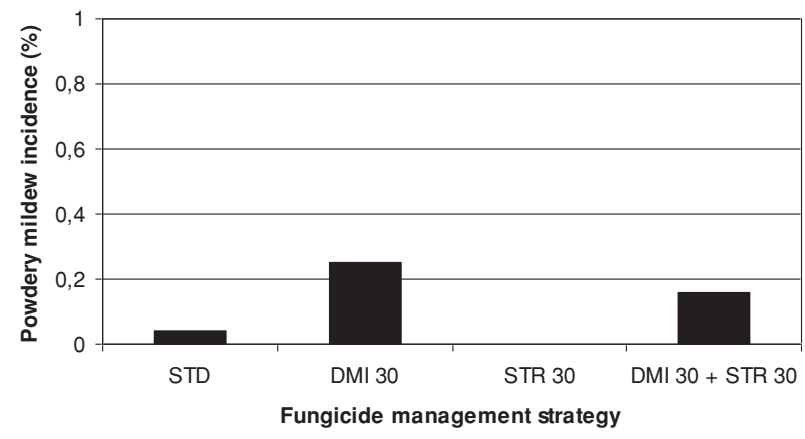

Figure 4. Efficacy of DMI and strobilurin spray programmes $(\mathrm{STD}=$ Standard, DMI 30 = DMI dominant, STR 30 = strobilurin dominant, DMI 30 + STR $30=$ DMI and strobilurin dominant) on powdery mildew incidence on shoot of cultivar Jonagold in 2010 at Ófehértó $\left(\operatorname{LSD}_{0.05}=0.4\right)$. 
Our study clearly demonstrated that further multiyear studies are necessary to evaluate the effect of DMI and strobilurin fungicide combinations on the control of apple scab and powdery mildew in a season-long disease management programme.

\section{Acknowledgements}

The study was supported by the NKTH programme (OM-00227/2008 and OM-00270/2008) and by the research programme of OTKA (K 78399) as well as by a János Bolyai Research Fellowship.

\section{References}

Délye, C., Laigret, F. \& Corio-Costet, M.F. (1997): A mutation in the 14-alpha demethylase gene of Uncinula necator that correlates with resistance to a sterol biosynthesis inhibitor. Applied and Environmental Microbiology, 63: 2966-2970.

Holb, I.J. (2005): Effect of pruning on disease incidence of apple scab and powdery mildew in integrated and organic apple production. International Journal of Horticultural Science, 11. (1): $57-61$.

Holb, I.J. (2006): Effect of six sanitation treatments on leaf litter density, ascospore production of Venturia inaequalis and scab incidence in integrated and organic apple orchards. European Journal of Plant Pathology, 115. (3): 293-307.
Holb, I.J., Heijne, B. \& Jeger, M.J. (2006): Effects of a combined sanitation treatment on earthworm populations, leaf litter density and infection by Venturia inaequalis in integrated apple orchards. Agriculture, Ecosystems and Environment, 114: 287-295.

Holb, I.J., Heijne, B., Withagen, J.C.M., Gáll, J.M. \& Jeger, M.J. (2005): Analysis of summer epidemic progress of apple scab in different apple production systems in the Netherlands and Hungary. Phytopathology, 95: 1001-1020.

Holb, I.J., Fazekas, M., Abonyi, F., Lakatos, P., Thurzó, S., Nyéki, J., Szabó, Z., Kruppa, J. \& Balla, B. (2009): Effect of reduced spray programmes on incidences of apple scab, powdery mildew and codling moth damage in environmentally freindly apple production systems. International Journal of Horticultural Science, 15. (4): 75-78.

Hollomon, D. W. \& Wheeler, I. E. (2002): Controlling powdery mildews with chemistry. In: The Powdery Mildews. A Comprehensive Treatise (Eds. Bélanger RR, Bushnell WR, Dik AJ \& Carver TLW), American Phytopathological Society, St. Paul, USA. pp. 249-255.

Jobin, T. \& Carisse O. (2007): Incidence of myclobutanil- and kresoxim-methyl-insensitive isolates of Venturia inaequalis in Quebec orchards. Plant Disease, 91: 1351-1358.

Koller, W., Wilcox, W.F., Barnard, J., Jones, A.L. \& Braun, P.G. (1997): Detection and quantification of resistance of Venturia inaequalis populations to sterol demethylation inhibitors. Phytopathology, 87: 184-190.

Zalom, F.G. (1993): Reorganizing to facilitate the development and use of integrated pest management, Agric. Ecosyst. Environ. 46: $245-256$. 